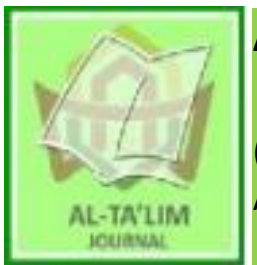

AL-TA'LIM JOURNAL, 27 (3), 2020, (236-248)

(Print ISSN 1410-7546 Online ISSN 2355-7893)

Available online at http://journal.tarbiyahiainib.ac.id/index.php/attalim

\title{
School Climate in Improving Conducive Learning Quality in MIN 2 Sibolga
}

\author{
Received: $08^{\text {th }}$ April 2020; Revised: $15^{\text {th }}$ November 2020; Accepted: $30^{\text {th }}$ Desember2020 \\ Permalink/DOI: https://doi.org/10.15548/jt.v27i3.623
}

\section{Syafaruddin *) \\ Universitas Islam Negeri Medan, Indonesia \\ E-Mail: syafaruddinsiahaan@uinsu.ac.id}

\section{Salim}

Universitas Islam Negeri Medan, Indonesia E-Mail: $\underline{\text { salim@uinsu.ac.id }}$

\section{Zulfikar Pasaribu}

Institut Agama Islam Negeri Padangsidempuan, Indonesia

E-mail: ucokmada1981@gmail.com

\section{*) Corresponding Author}

\begin{abstract}
School climate is "heart" and "breath" in a school. It relates to all interaction componentsamong school members from culture, social until the harmonization of the learning environment which affects the output quality. This study discusses the school climate in increasing learning quality in MIN (State Islamic Primary School) 2 Sibolga. The scope of the study focused on how to produce a school climate and its role in improving learning quality in MIN 2 Sibolga. This study applied the qualitative approach and school activities as the object of the study, such as daily routine, programmed activities, and selfdevelopment activities. The result of the study showed that a "conducive" school climatewas created well in MIN 2 Sibolga, it could be seen from (1) creating a conducive learning climate, (2) managing school environment, (3) developing school psychologic-cultural routines, and (4) improving "discipline" culture for school members. However, there were some obstacles, such as inadequate infrastructure, low teacher competence, less financing, less student development, and lack of training for the teachers.
\end{abstract}

Keywords: Cnducive; learning; quality; school climate.

How to Cite: Syafaruddin, S., Salim, S., \&Pasaribu, Z. (2020). School Climate in Improving Conducive Learning Quality in MIN 2 Sibolga. Al-Ta lim Journal, 27(3), 236-249. doi:https://doi.org/10.15548/jt.v27i3.623

\section{INTRODUCTION}

School is a "medium" in developing students' potency (Seyfarth, 1991). Therefore, school climate needs to be considered in order to produce students' potency (Brookover et al., 1978), and create an effective school environment (Mutmainah, 2017; Setiawan, 2016; Welsh, 2000). School climate is created naturally and scientifically. Naturally means the process of culturing happened in the school environment, while scientifically relates to the efforts of implementing policy and "manipulative" activities to improve school quality.

\section{Regors\& Freiberg define school} climate as a thing indicating school quality (Freiberg, 1999). It is indicated by "healthy" learning, keeping students' rights, aspiration, parents' "dream", stimulating teacher's creativities, and "welfare" of school members. The created school climate is related to leadership, school culture, and personality of school members.Besides, the school climate characterizes an affected and 
unmeasurable thing (Ashkanasy \& Jackson, 2002). Therefore, the effort to condition the school climateis related to three dimensions: leadership, culture, and personality of the school members.

Based on a previous study in MIN 2 Sibolga, the researcher found the first data that the created school climate in MIN 2 Sibolga showed the culture supporting active learning and a healthy environment.Further, the researcher interested to choose school activities in MIN 2 Sibolga as the background of the research was due to three aspects: (1) MIN 2 Sibolga is placed in front of SDN 087659 and makes MIN 2 Sibolga improve its quality continuously as a competitive effort to attract public attention, (2) MIN 2 Sibolga has two school buildings in two different districts so it makes a challenge as well as an opportunity in creating school climate, and (3) achievements in MI (Islamic School) level in Sibolga.School climate is a "heart" and "soul" for a school (Freiberg, 1999: 11).It is the essence of school leadership, communication of school members, and the manifestation of school activities in creating a sense of "having" and "loving" school.

In the last ten years, the previous research has discussed school climate from different aspects, such as the relation between school climate and personality of school personnel (Assingkily \& Mesiono, 2019; Halawah, 2005; Hapsari, 2014; Magfirah \& Rachmawati, 2010), and culture of school members (Alfiansyah et al., 2020; Fiteriani, 2015), leadership (Aminullah et al., 2014; Black, 2010; Wan Roslina, 2011), learning motivation (Rahayu, 2020; Razak, 2006), the performance of school personnel (Bahri, 2010; I. Rahmawati, 2011; Yuliejantiningsih, 2012), job satisfaction (Collie et al., 2012; Fitriana, 2013; Sumarsono, 2012; Zullig et al., 2011), productivity (Komariah, 2014), and school quality (Damayanti, 2017; F. Rahmawati, 2013).

According to these related studies, there is a gap related to school climate, namely school climate and its role in improving learning quality which is able to create "conducive" conditions in educational institutions, especially for MI/SD (Primary) level.

Related to this issue, learning quality becomes an important thing in creating a school climate. Thus, "compilation" and "collaboration" of culture, social, and other school aspects becomes a main component to be developed. Likewise, obstacles, solutions, factors, and efforts to create a school climate are also important to be discussed deep. Based on the previous and related studies, it is important to conduct deep research on school climate with the theme: "School Climate in Improving "Conducive" Leaning Quality in MIN 2 Sibolga".

\section{METHOD}

This study focused on school climate. This empirical study is conducted to analyze school climate in improving learning quality, both inside and outside the classroom in MIN 2 Sibolga. Thus, the qualitative approach was considered suitable to explore the facts as an empirical truth in this research (Mayring, 2004; Patton, 1990; Silverman, 2020; Stake, 2005).

The object of this study was the created school climate in MIN 2 Sibolga as an effort to improve learning quality. Data were collected through deep interviews, observation, and study documentation. Then, the data were analyzed continuously from the beginning until the end of the study by data reduction, data display, and drawing conclusions. To ensure validity, a triangulation technique was applied for sources and methods (Ayres et al., 2003; Bazeley, 2013; Sgier, 2012). Thus, credibility, dispensability, dependability, and confirmation were conducted. Based on the explanation above, the school climate cycle framework in MIN 2 Sibolga could be seen in the picture as follows. 


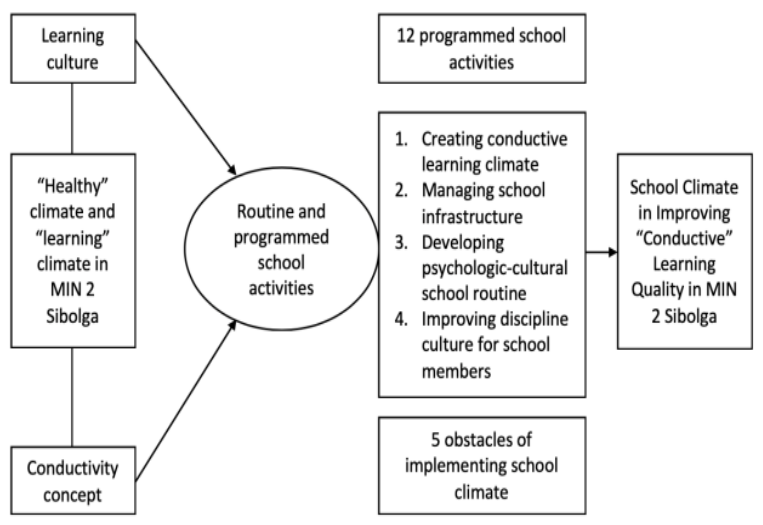

Figure 1. Research Flow Scheme

\section{RESULT AND DISCUSSION}

\section{MIN 2 Sibolga Short Description}

Madrasah Ibtidaiyah Negeri (MIN) 2 Sibolgais a school build in 1989. It is located on Jl. SM. Raja Gg. Aek Horsik, Kelurahan Aek Manis, Kecamatan Sibolga Selatan, Kota Sibolga, North Sumatra.MIN 2 Sibolga is also one of two state Islamic Primary Schools in Sibolga, while four other Islamic primary schools are private schools, so there are six Islamic primary schools in Sibolga. This school is directly located in front of SDN 087659 Kota Sibolga. In the first place, this school was Madrasah DiniyahAwaliyah (MDA)-Islamic School for children to learn how to recite Al Qur'an- in the afternoon. Based on Gusniar's explanation, due to the inability of the MDA owner to runschool operations, the school was given to the Country under Minister of Religion management and changed its name to be MIN AekHabil, and since 2019 it has named MIN 2 Sibolga.

Its location which is directly placed in front of SDN 087659 gives chance as well as a challenge for the school personnel. One of the challenges isthat MIN 2 Sibolga does not have its own field since it was built 31 years ago, so it has to use SDN 087659 field. Also, the close position of the schools makes MIN 2 Sibolga must be competitive in the interacting public interest and adjusts public needs through recommended activities and school routine. Here is the documentation of MIN 2 Sibolga and SDN 087659 position.

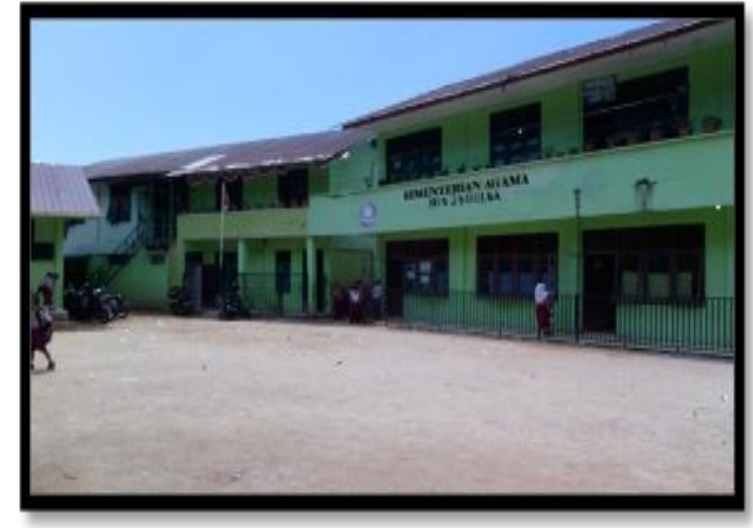

Figure2. Field of MIN 2 Sibolga

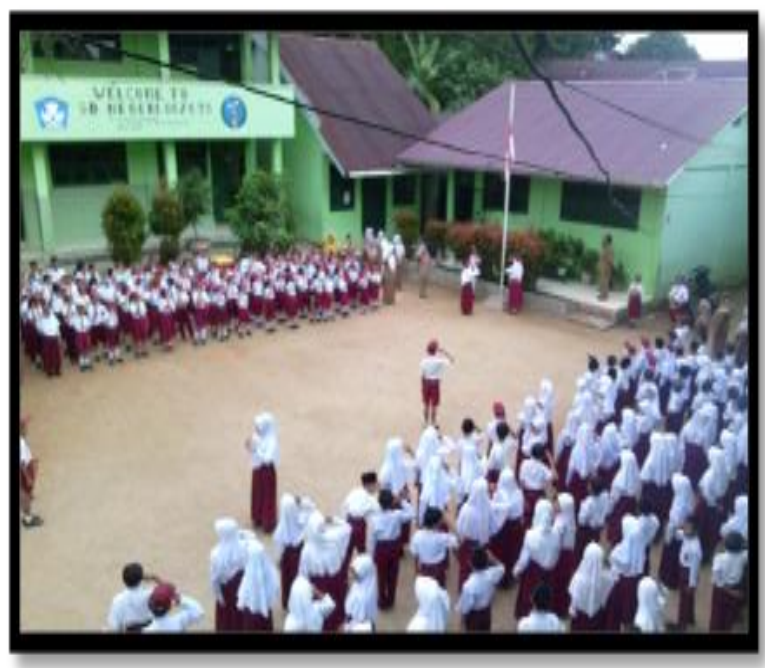

Figure3. Field of SDN No. 087659

In the current development, MIN 2 Sibolga has two buildings located in two different districts. The first building is known as "MIN Kaje-Kaje" or its old official name as "MIN Aek Habil", located on JL. SM. Raja Gg. Gotting Kelurahan Aek Parombunan.

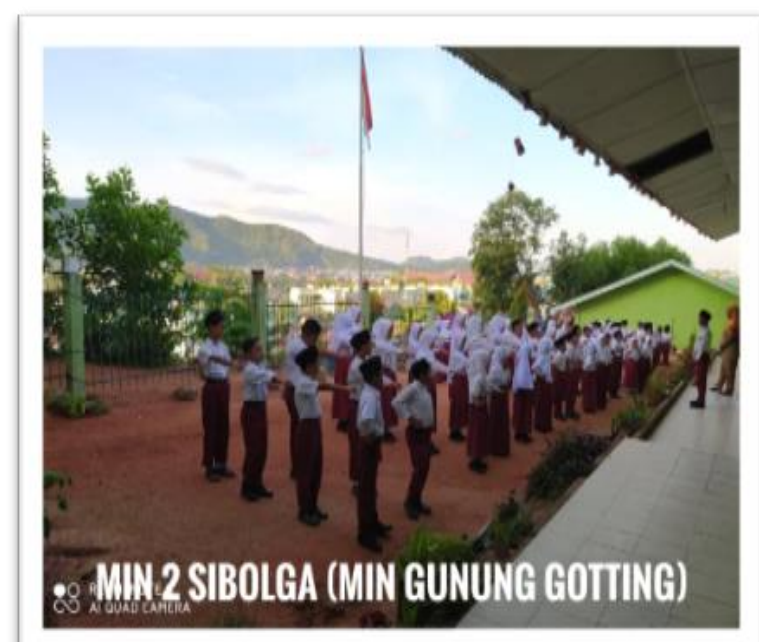

Figure4. The $2^{\text {nd }}$ Building MIN 2 Sibolga 
Uniquely, the second building of MIN 2 Sibolga or also known as "MIN Gunung" is located atthe top of a mount with a height of \pm 30 meters, while its left and right side, as well as the front, is ravines.Nevertheless, MIN 2 Sibolga is one of the "best MI" under the Sibolga Ministry of Religious for its achievements, number of students, and output of the school at Sibolga MI level.Based on the school description above, it could be understood that MIN 2 Sibolga is built as an effort to continue the "relay" of Islamic education to fulfill children's needs of learning religion informal educational institution, in form of MI in Sibolga.

\section{"Healthy" Routine and "Learning" Climate in MIN 2 Sibolga}

"Healthy" school climate and "learning" climate in MIN 2 Sibolga is carried out in programmed school activities and routine by school members. Inline, (Syafaruddin, 2015) explained that the climate is centered on the relation and interaction of a system in a group of humans or an organization. The "fruit" of the interaction is matched to programmed activities and routines.A good or bad climate in school will affect the learning quality. It is in line with (Goetsch \& Davis, 2014) explanation of climate as a unity of school personnel and learning process. The characteristic of unity is service, response, environment or climate, and structuring selection (manipulation).

Related to the explanation above, some climate created in MIN 2 Sibolga are (1) collecting rubbish activity, (2) lining up in the yard every morning, (3) praying before entering the classroom, (4) late and punishment, (5) uniform, (6) poster, (7) handshaking with the teacher, (8) memorizing one day one Qur'anic verse, (9) habituationof "tayyibah sentence", (10) educational punishment, (11) praying "kafaratul majlis" before closing the learning process, and (12) self-development for students.

\section{Collecting Rubbish Activity (CRA)}

Collecting rubbish activity is a cleanlife culture and loving environment practiced daily by the students in MIN 2 Sibolga.

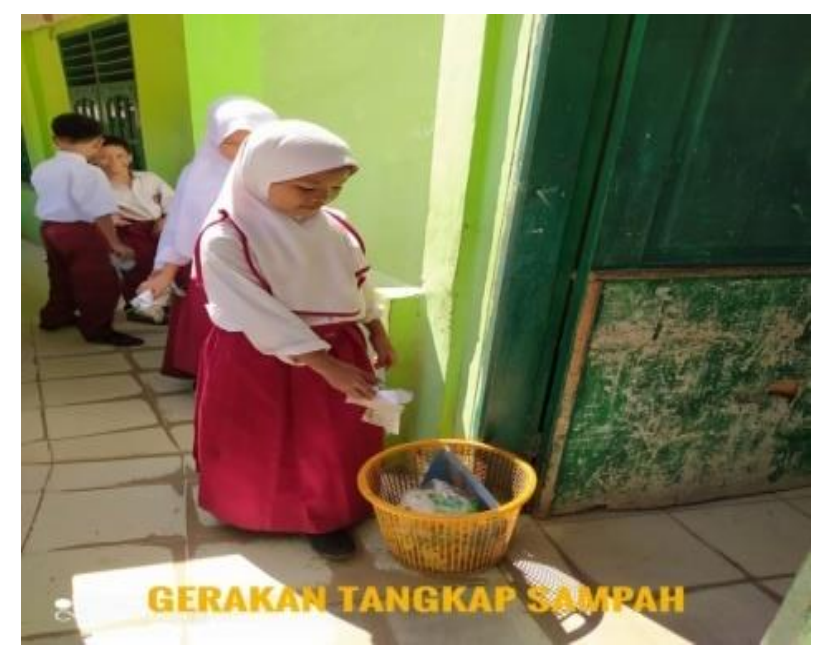

Figure 5. Collecting Rubbish Activity (CRA)

This activity is carried out to train students' awareness of a loving school environment. The form of this activity is every morning the students "must" collect rubbish at least three kinds of rubbishes in the schoolyard, and throw it to the trash can. Similarly, (Solikah, 2018) says how important this habituation is in building students' awareness of a clean and healthy life for students at the primary level. Commenting on that opinion, (Candrawati \& Widiani, 2015) argue that it is important to do UKS (student health unit) program optimally by living clean and healthy for the young learners. Therefore, "collecting rubbish activity" indicates a "healthy" climate created in MIN 2 Sibolga. Based on those explanations, it means that "collecting rubbish activity" is a good culture which indicates a school climate created by "conducive" learning quality in MIN 2 Sibolga.

\section{Lining Up in School Field Every Morning}

Lining up every morning in the school field is a routine done by MIN 2 students. This routine involves reading asmaulhusna, short Qur'anic verses, daily Islamic prayer, short Islamic speech, and gymnastics. This activityis guided by the teachers. For the wellrun of this activity, the school personnel also arrange a picket schedule. The schedule is on the table as follows: 
Tabel 1. The Picket Schedule of Morning Lining Up

\begin{tabular}{|c|c|c|c|}
\hline No & Day & Activity & Picket Teacher \\
\hline 1. & Monday & Flag Ceremony & $\begin{array}{l}\text { Irma Suryani, S.Pd.I } \\
\text { Devita Sari, S.Pd }\end{array}$ \\
\hline 2. & Tuesday & Asmaul Husna\&Short Qur'anic verse & $\begin{array}{c}\text { Siti Aini Sinaga, S.Pd.I } \\
\text { EldiawatiHarahap, S.Pd.I }\end{array}$ \\
\hline 3. & Wednesday & $\begin{array}{l}\text { Asmaulhusna\& } \\
\text { Daily prayers }\end{array}$ & $\begin{array}{c}\text { Drs. Mulkan } \\
\text { Ida SyamNadeak, S.Pd.I }\end{array}$ \\
\hline 4. & Thursday & $\begin{array}{l}\text { Asmaulhusna\& } \\
\text { Hadits }\end{array}$ & $\begin{array}{c}\text { Vera wati, S.Pd.I } \\
\text { HanniKholidah, S.Pd.I }\end{array}$ \\
\hline 5. & Friday & Gymnastics & $\begin{array}{l}\text { Oscar Fernandes, S.Pd. } \\
\text { Fitriani, S.Pd.I }\end{array}$ \\
\hline 6. & Saturday & $\begin{array}{c}\text { Tilawah(reciting Qur'an) \& } \\
\text { Kultum(Short Islamic speech) }\end{array}$ & $\begin{array}{c}\text { IrpanSaputra, S.Pd.I } \\
\text { SuryaniTanjung, S.Pd.I }\end{array}$ \\
\hline
\end{tabular}

Based on the table, it means that regularity and the effort of setting up students' initiative to line up every morning independently should be supported by a scheduled accompaniment.Inline, (Gunbayi, 2007) argues that school climate involves various complex norms, values, hopes, policies, and procedures affecting individual and group behavior.According to this explanation, it means that lining up activity containing the reading from Al Qur'an and Hadits (Prophet Muhammad's words) indicates a good school climate because it could improve learning quality through scheduled picket teacher accompaniment in MIN 2 Sibolga.

\section{Praying Together before Entering the Classroom}

Praying together before entering the classroom is a morning routine done by school members in MIN 2 Sibolga.The prayer is uttered in Arabic, as to how the daily Islamic prayer memorized by the students. Then, the students pray together again in the classroom and read 2-5 short surah in which reciting, makhraj, and tajwidare under teachers' supervision. Uniquely, this activity is done by MIN 2 students together with SDN 087659 students. It happened because the school buildings are face-to-face position, and using the same school field. So that, based on mutual agreement, both of the schools do not concern in habituation activity done togetherbytheir students. This activity shows a climate supporting the improvement of school quality.

Inline, (Haynes et al., 2009) argue that a school climate is a form of quality and consistency of interpersonal interaction in school members affecting students' cognitive, social, and psychology.So, practicing pray together before entering the classroom becomes an important thing to create a conducive or "comfortable" school climate in MIN 2 Sibolga.

\section{Late and Punishment}

Late and punishment is an affirmation inflicted by the school personnelon the students. It is begun by socializing it to the students as a disciplined exercise. So, before coming late, the students knew the consequences.

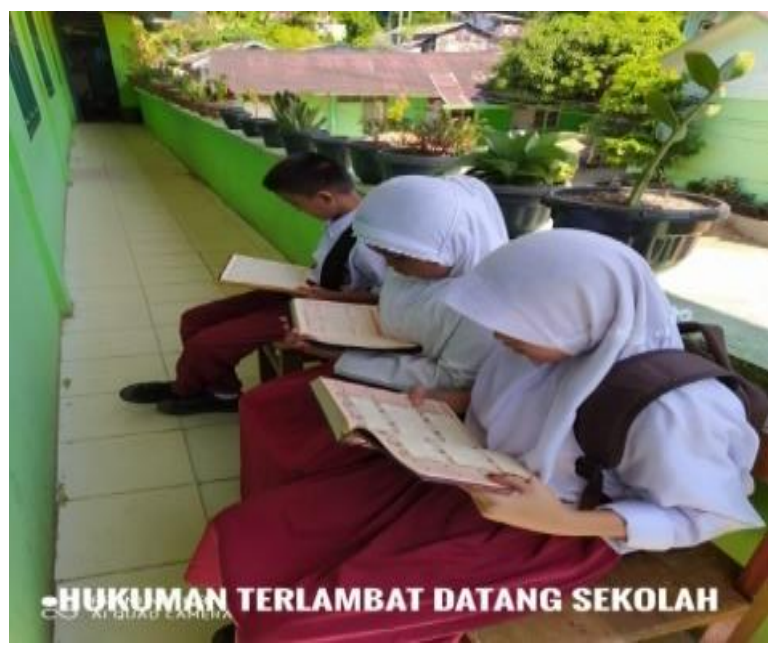

Figure6. Punishment to the Students who Come Late 
Based on this picture, the students are punished by reciting Al Qur'an instructed by the teacher. It is in line with Siti Aini Sinaga's argument that the students who come late are punished. The students in grades 1-3 are punished by memorizing asmaul husnah, while grades 4-6 are asked to memorize short Qur'anic surah, hadits, and daily prayers. Related to the punishment, Insyiroh explains that inflicting punishment on the students who come late is important. However, before inflicting the punishment on the students, the teacher should ask the reasonsfor their tardiness, give counseling to the students, ask the students' perceptions on their punishment, and evaluate the result of handling (Insyiroh, 2017).

The above explanation is in line with (Yuniarn, n.d.) argument that it is important to use an educative punishment to exercise students to be disciplined. So, the students feel like being watched and receive counseling if they make a mistake. Based on that explanation, it could be synthesized that MIN2 Sibolga personnel still inflict punishment for the students' mistakes. However, to ensure the students do not feel humiliated and underestimated, so the created climate is by inflicting educative punishment in order that the students "feel like being guided" by the teachers.

\section{Uniform}

Uniform is an important thing to show school identity. The MIN 2 Sibolga uniform is following the color and model regulated by the government. Further, there is a unique in MIN 2 Sibolga students' uniform in which according to Sibolga Education Authorities instruction, the male wears trousers, and the female wearsa long skirt and craft.

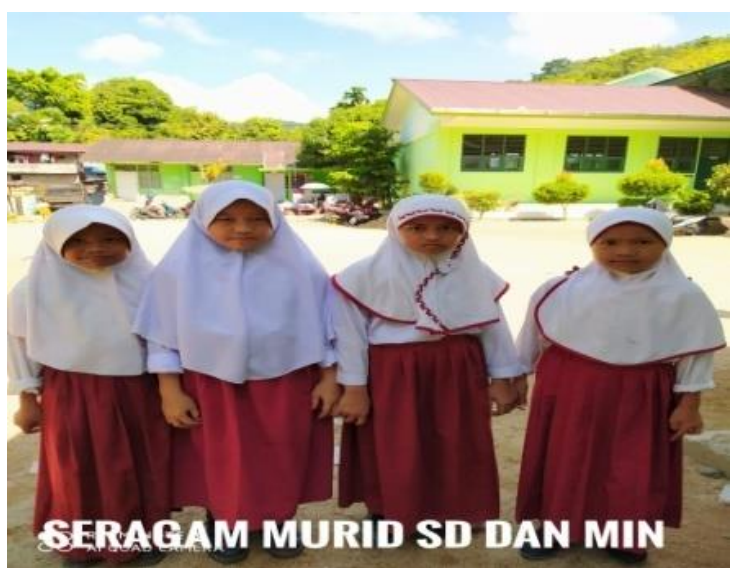

Figure7.MIN 2 Sibolga and SDN 087659 Student Uniforms

According to the picture, the scarf worn by MIN 2 Sibolga and SDN 087659 students is different in which the MIN students' craft is longer than those of SDN students.Based on internal school policy, MIN 2 Sibolga students are to wear long craft, so covering their aurat is engraved since young. (Aziz, 2014) says that wearing cloth based on Islamic law is an important thing to be educated to the students since young because it is an effort of appropriate sex education for the students.

In line with the above opinion, (Irsyad, 2019) argues that clothing is an urgent matter to be educated to children since young, so there will be assistance and prevention at the same time.According to the above opinion, it could be synthesized that the effort of MIN 2 Sibolga personnel in imposing the rule of wearing neat and polite clothes becomes a "shield" and creates a "positive" climate for the students.

\section{Poster}

The poster is a visual display on the school wall. The posters displayed by the school personnel are contained pray, hadith, and religious advice. Even, every classroom, chair, table, cupboard, and the window are pasted its poster name in Arabic. 


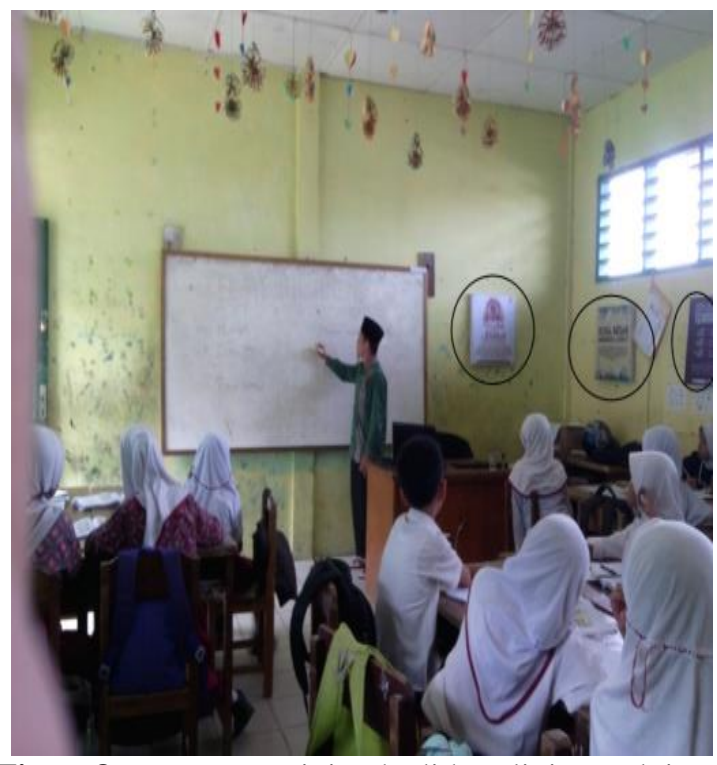

Figure8. Poster containing hadith, religious advices, and prayers displayed on the wall.

Based on the picture, commonly the students will be attracted to see the posters. It is because the posters are displayed on an ideal spot for young learner vision. Further, the posters displayed by the school personnel are as follows.

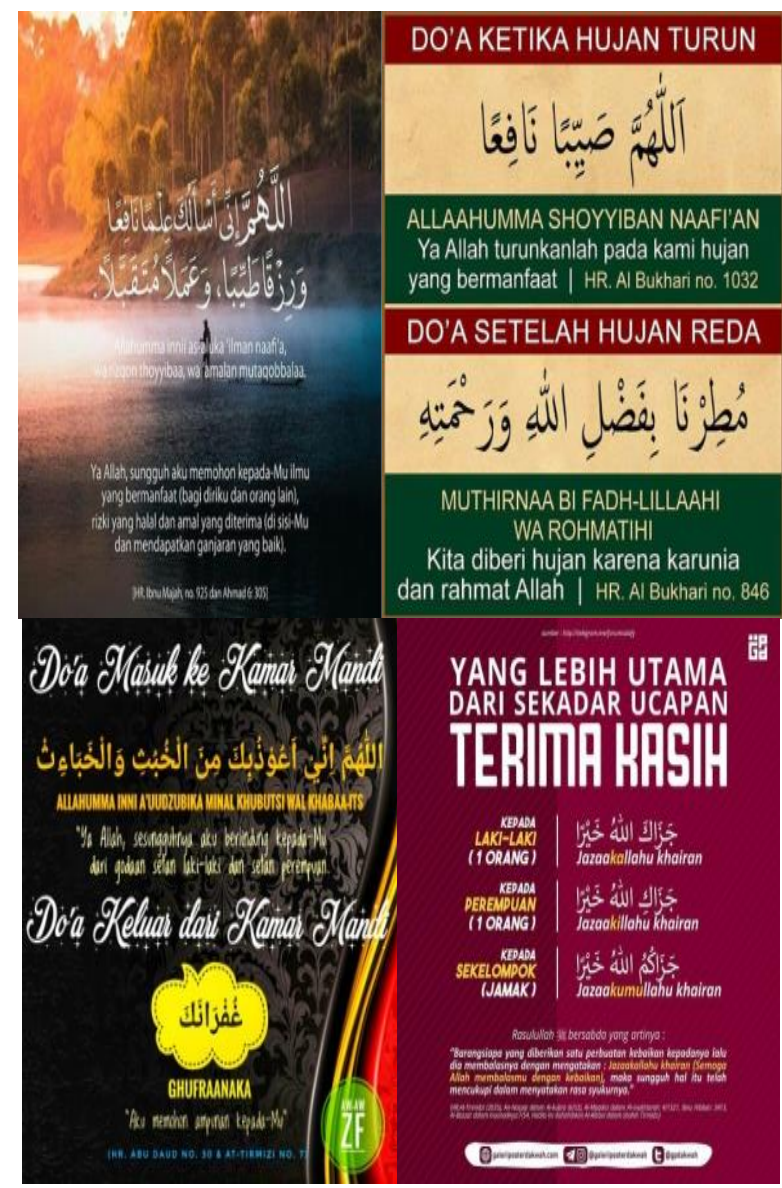

Figure 9. Some Examples of Posters Dispalyed in the Classroom.
According to the picture, it could be seen that Qur'anic verses, hadith, and Arabic names of things are the priority posters in MIN 2 Sibolga.Related to the explanation above, (Anggraini, 2017) explain the young learner loves that picture, so it helps form students' character value.Based on the explanation above, it could be seen that poster is a media helping the school personnel in creating a "healthy" and "learning" climate, also forming character values for the MIN 2 Sibolga students.

\section{Handshaking with the Teachers}

Handshaking is one of the good activities applied in MIN 2 Sibolga. This activity is applied after lining up in the schoolyard every morning. All students shake the teacher's and principal's hands. Similarly, all the teachers shake hands with one another as an example for the students. Uniquely, since a young age, the male students are taught not to shake female teachers' hands directly but press their hands together with the fingers pointing up and smile to the teachers. Similarly, the female students do it to the male teachers.

Regarding the explanation above, (Pohan et al., 2017) explain that handshaking is an important activity in building students' character from a young age (primary level).Even, handshaking also builds a closeness between students and teachers as well as the school members.Based on the explanation above, it could be seen that handshaking is a form of good "school climate" in MIN 2 Sibolga because it could strengthen ownership, love, tolerance, as well as mutual respect forschool members.

\section{One Day One Ayat (Qur'anic verse)}

This activity is applied to pay attention to students' recitation. This activity is carried out by asking the students to memorize one Qur'anic verse one day by applying sima' $i$ method. 


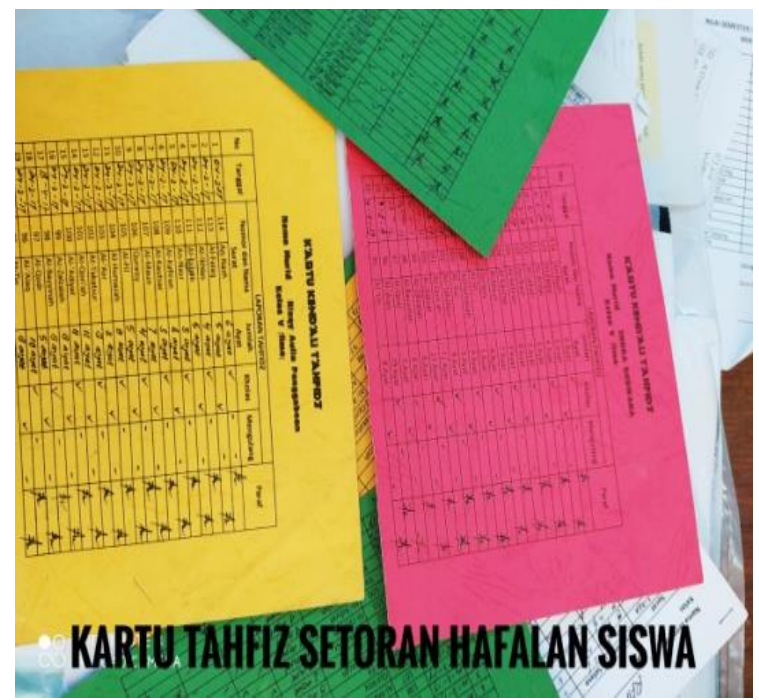

Figure10. Student's Recitation Card

A recitation card is a written report of students' recitation development. It is considered to be important to raise students' spirit and appreciate the process passed by the students.Inline, (Firdausi \& Hidayah, 2018) explain that recitation by giving sorogan cards could stimulate students to improve their recitation.Regarding the explanation above, the effort of creating school climate as soul and heart of the school (Pretorius \& De Villiers, 2009), is required changing the culture that students received from their homes to school, and it is affected by the policy, leadership style, belief, values, and productivitiesapplied in school (Syafaruddin, 2019). Even, this social subjectivity creates the Qur'anic contextualization in school (Assingkily, 2019; Assingkily \& Baroroh, 2017; Assingkily \& Hardiyati, 2019).

Based on the explanation above, it could be seen that the implementation of one day one ayat activity becomes a policy affecting the forming of character value to the students in which the students are guided to be a spirit, brave, and to use time productively. It indicates the school climate created well in MIN 2 Sibolga.

\section{Habituation of Tayyibah Sentence and Pray Together}

Habituation of tayyibah sentence is an effort to train the students to say good and useful words, so it could help the students not bully each other in the school.The forms of the habituation of tayyibah sentence are (1) by changing the word "thank you" to be jazakallah/jazakillah/jazakumullahhairankats iran"; (2) to habituate to say Alhamdulillah, Subhanallah, Allahu Akbar, InsyaAllah, MasyaAllah, andistighfar; (3) to habituate to call "anak Bapak/Ibu" by the teachers to the students, and the "naughty" students are called "anaksholeh".

These habituations are to guide the students to say good things, and indirectly to pray for one another so as to get the blessing and "conducive" climate in the school. Further, pray together activity is done two times, Dhuha prayer and Zuhur prayer.

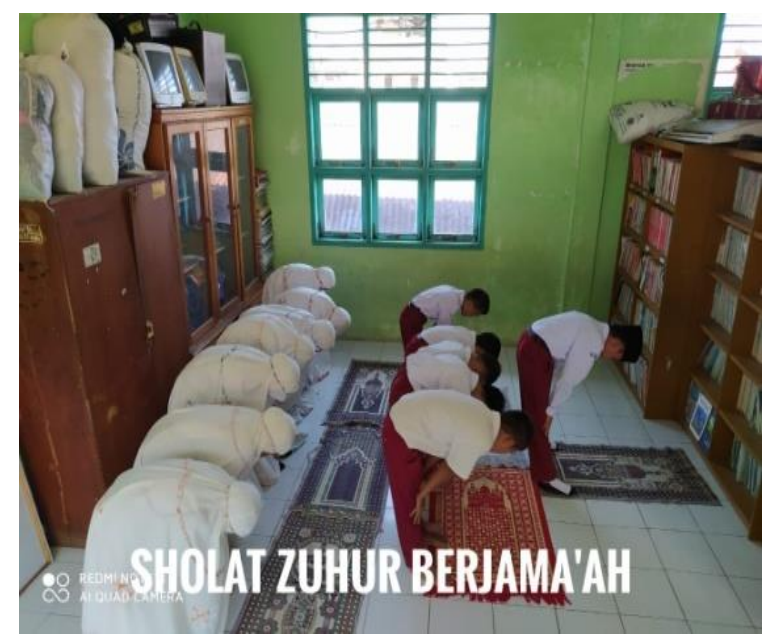

Figure 11. Pray Together in MIN2Sibolga

According to (Agustina, 2018), religious practice, such as pray together and say tayyibah sentence, is a form of "manifest" of the leadership characteristic of the principal in creating school culture, or also called school climate.Based on the explanation above, it could be seen that the habituation of tayyibah sentence and praying together are a sequence activity supporting a creating school climate in improving the quality of the "conducive" learning process in MIN 2 Sibolga.

\section{Educative Punishment}

A punishment is commonly related to a "scary" thing and acts as a deterrent to the offenders (Barrett \& Toma, 2013; Moberly et al., 2005; Weijers, 2000). However, MIN 2 Sibolga does differently in which punishment is an educative process. The punishment form 
is saying istighfar (as a self-confession of making mistake) and writing it on a paper.

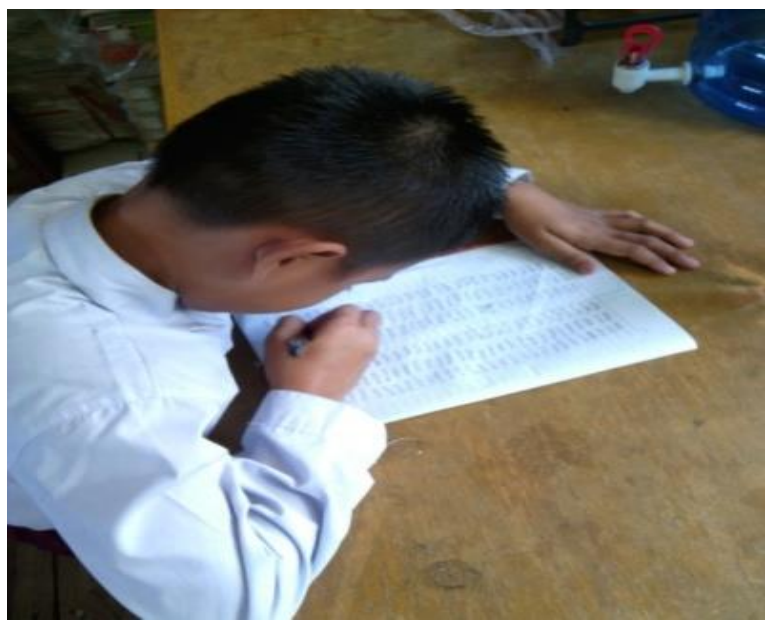

Figure 12. The student who is the offender is asked to write "istighfar" in his book.

Based on the picture above, it could be seen that although the students are the offenders, they are still given guidance. Supporting it, (Yuniarn, n.d.) explain that the urgency of inflicting punishment is important. However, it should build discipline character in students' selves. So, the students feel like being watched and guided when making mistake.

\section{Self Development for Students}

Self-development is a given discretion to the students to improve their potential. It is supported by spirit and activity facilities given by MIN 2 Sibolga.The selfdevelopment refers to learn PAI (Islamic teachings) material deeply, including reading, writing, memorizing Qur'anic verse and hadith, and practicing ablution procedures, salat (prayer), zikir, and praying.

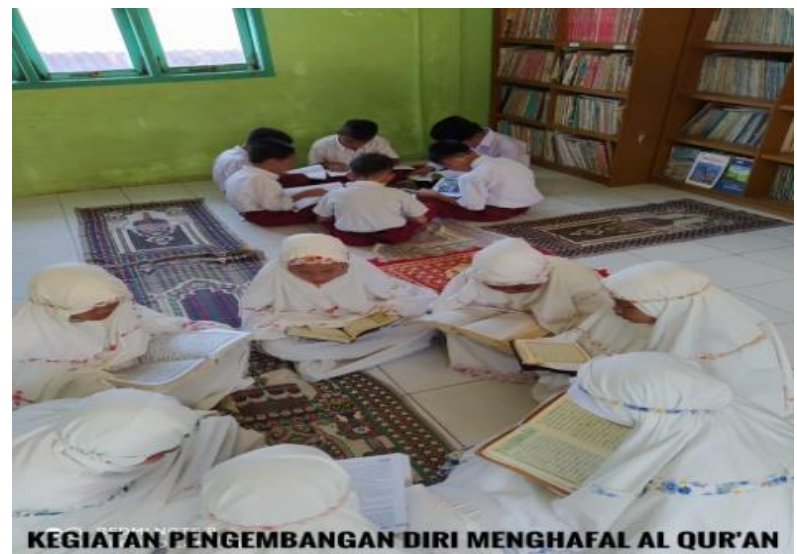

Figure 13.Self-development Activity
This activity is done every Friday for three learning sessions or $3 \times 35$ minutes. The adequate time allocation and good guidance could help the process of students' selfdevelopment, included cognitivepsychomotor, social-emotional (Assingkily \& Hardiyati, 2019), language-art, religion, and moral values.Based on the explanation above, it could be seen that self-development activity could improve the quality and conducive climate in MIN 2 Sibolga, this conducive sequence is known as the school climate.

\section{School Efforts in Creating "Conducive" Learning in MIN 2 Sibolga}

School climate has happened from the habit had by school members. It is driven by the leader policy, character building, and embodiment of ownership and loving school. Therefore, it is required doing an effort in order that school memberscollaborate consciously and together to create a school climate in improving "conducive" learning quality in MIN 2 Sibolga.The efforts are (1) creating a conducive learning climate, (2) managing schoolinfrastructure, (3) developing school psychology-cultural routine, (4) improving discipline for all school members.

\section{Creating "Conducive” Learning Climate}

All school members should do on effort of creating conducive learning climate. In line with this opinion, (Tubbs \& Garner, 2008) state that a school climate is a form of school quality, namely learning quality, institution quality, alumnus quality, even "process" quality reflected by an education institution.Related to this argument, the form of the created climate classification is the actions of school members, including the principal, teachers, and the students in MIN 2 Sibolga.The principal, teachers, and the school staff are expected to work sincerely to gain maximum achievement of the school goals.

The teachers are expected to be able to understand the students on their intellectual, social-emotional, and individual characteristics. Then, the teachers are able to 
facilitate the learning process for all students, see the students equally, motivate the students, and perform good role models in order to be an adviser as well as a "parent" for the students. Inline, the students are expected to be able to communicate well and actively with the teachers and school principal. Further, in the school it is also created a learning climate with the concept of (1) establishing clear rules, (2) guiding the good attitudes and what the students should avoid, (3) explaining the consequences of students' actions so the students consciously and accountably know their actions.

\section{Managing School Infrastructure}

Managing school infrastructure is done by (1) organizing a classroom where the lower grade is on the first floor, and the higher grade is on the second floor.

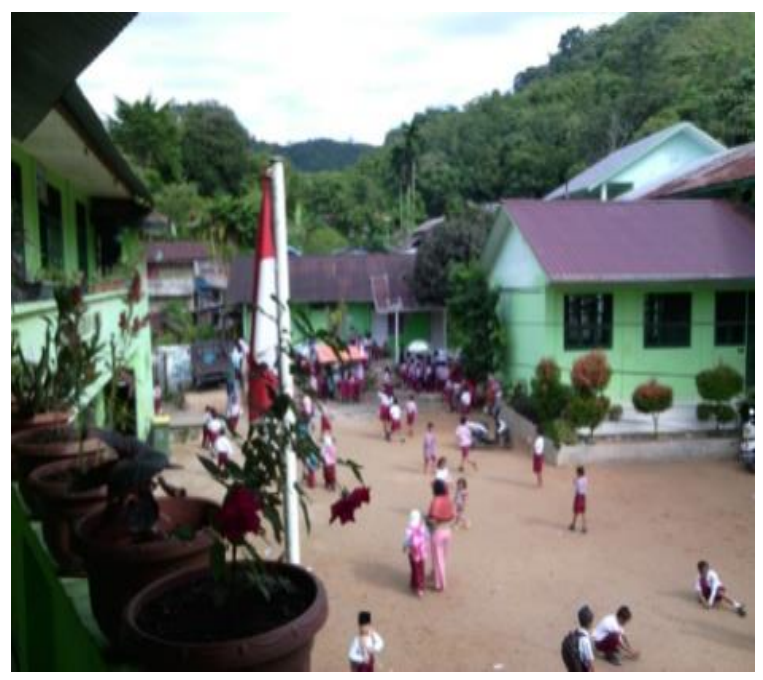

Figure 14. Flower and Infrastructure Management in MIN 2 Sibolga

Then, (2) managing flowers and class garden. This activity is to create a "beautiful" school to give fresh, and spirit in the learning process; and (3) to enforce students' passion, the school has a clean, neat, and beautiful classroom competition every semester.

\section{Psychology-Cultural Development}

The psychology-cultural development is a school routine, such as flag ceremony, gymnastics, reciting and memorizing
Qur'anic verses, hadith, daily prayers, and student character building in MIN 2 Sibolga.

Improving Discipline Culture for All School Members

Discipline culture is an effort to build awareness of school members in obeying the school rules. Improving discipline culture is expected to make the school members do things due to awareness and ownership of the school. Therefore, the school members will be discipline with or without rewards and punishments.

\section{Obstacles in Creating School Climate in MIN 2 Sibolga}

School is the "medium" in producing superior human resources, of course by creating a "learning" and "healthy" climate first in the school. However, a problem, as a normal process in managing an institution, causes an obstacle and problem in creating a school climate, including a found obstacle in MIN 2 Sibolga.

Some obstacles faced by school personnel in creating a school climate to improve learning quality in MIN 2 Sibolga are (a) inadequate infrastructure (such as field), (b) teacher competences, (c) financing, (d) students' development, and (e) lack of teacher training.

\section{CONCLUSIONAND RECOMMENDATION}

Based on the findings and data analysis, it could be concluded that school "healthy" and "learning" climate was created well in MIN 2 Sibolga. It could be seen from the efforts to (1) create a conducive learning climate, (2) manage school infrastructure, (3) develop school psychologic-cultural routine, and (4) improve discipline culture among school members. However, still could be found some obstacles as inadequate infrastructure, teacher competence, financing, students' development, and lack of training for the teachers. 


\section{REFERENCES}

Agustina, P. (2018). Karakteristik perilaku kepemimpinan kepala sekolah dan budaya sekolah di Sekolah Dasar. Jurnal Pendidikan Karakter, 8(2).

Alfiansyah, M., Assingkily, M. S., \& Prastowo, A. (2020). Kebijakan Internal Madrasah dalam Meningkatkan Mutu Pendidikan di MI Nurul Ummah Kotagede Yogyakarta. MAGISTRA: Media Pengembangan Ilmu Pendidikan Dasar Dan Keislaman, 11(1), 52-67.

Aminullah, D., Tripalupi, L. E., \& Dunia, I. K. (2014). Pengaruh Kepemimpinan Transformasional Kepala Sekolah terhadap Iklim Sekolah pada SMP N 4 Negara. Jurnal Pendidikan Ekonomi Undiksha, 4(1).

Anggraini, N. A. (2017). Penerapan model pembelajaran Student Teams Achievement Division (STAD) dan Problem Silving untuk meningkatkan hasil belajar siswa pada mata pelajaran Ekonomi kelas X IPS MA Hidayatul Mubtadi'in Malang. Penerapan Model Pembelajaran Student Teams Achievement Division (STAD) Dan Problem Silving Untuk Meningkatkan Hasil Belajar Siswa Pada Mata Pelajaran Ekonomi Kelas X IPS MA Hidayatul Mubtadi'in Malang/Nia Amalia Anggraini.

Ashkanasy, N. M., \& Jackson, C. R. (2002). Organizational culture and climate.

Assingkily, M. S. (2019). Peran Program Tahfiz dan Tahsin Al-Qur'an dalam Meningkatkan Literasi Al-Qur'an Siswa di Madrasah Ibtidaiyah Nurul Ummah Kotagede Yogyakarta. Jurnal MUDARRISUNA: Media Kajian Pendidikan Agama Islam, 9(1), 186225.

Assingkily, M. S., \& Baroroh, R. U. (2017). Prototipe Living Qur'an Pendidikan Dasar di Madrasah Ibtidaiyah: Studi Kasus di MI Nurul Ummah Kotagede
Yogyakarta. JOIES: Journal of Islamic Education Studies, 2(1), 136162.

Assingkily, M. S., \& Hardiyati, M. (2019). Analisis perkembangan sosialemosional tercapai dan tidak tercapai siswa usia dasar. Al-Aulad: Journal of Islamic Primary Education, 2(2), 1931.

Assingkily, M. S., \& Mesiono, M. (2019). Karakteristik Kepemimpinan Transformasional di Madrasah Ibtidaiyah (MI) serta Relevansinya dengan Visi Pendidikan Abad 21. MANAGERIA: Jurnal Manajemen Pendidikan Islam, 4(1), 147-168.

Ayres, L., Kavanaugh, K., \& Knafl, K. A. (2003). Within-case and across-case approaches to qualitative data analysis. Qualitative Health Research, 13(6), 871-883.

Aziz, S. (2014). Pendidikan seks bagi anak berkebutuhan khusus. Jurnal Kependidikan, 2(2), 182-204.

Bahri, S. (2010). Peranan Kepemimpinan Kepala Sekolah dan Iklim Sekolah Terhadap Kinerja Guru. Visipena, 1(2), 30-39.

Barrett, N., \& Toma, E. F. (2013). Reward or punishment? Class size and teacher quality. Economics of Education Review, 35, 41-52.

Bazeley, P. (2013). Qualitative data analysis: Practical strategies. Sage.

Black, G. L. (2010). Correlational analysis of servant leadership and school climate. Journal of Catholic Education, 13(4), 437-466.

Brookover, W. B., Schweitzer, J. H., Schneider, J. M., Beady, C. H., Flood, P. K., \& Wisenbaker, J. M. (1978). Elementary school social climate and school achievement. American Educational Research Journal, 15(2), 301-318. 
Candrawati, E., \& Widiani, E. (2015). Pelaksanaan Program UKS dengan Perilaku Hidup Bersih dan Sehat (PHBS) Siswa Sekolah Dasar di Kecamatan Kedung Kandang Kota Malang. Care: Jurnal Ilmiah Ilmu Kesehatan, 3(1), 15-23.

Collie, R. J., Shapka, J. D., \& Perry, N. E. (2012). School climate and socialemotional learning: Predicting teacher stress, job satisfaction, and teaching efficacy. Journal of Educational Psychology, 104(4), 1189.

Damayanti, D. (2017). Kemampuan Manajerial Kepala Sekolah, Iklim Sekolah Dan Mutu Sekolah Dasar. Jurnal Administrasi Pendidikan UPI, 24(1), 154-162.

Firdausi, F., \& Hidayah, A. (2018). Kecerdasan Intrapersonal dan Pengaruhnya Terhadap Keberhasilan Santri Mahasiswa dalam Menghafal Al-Qur'an. Jurnal Studi Ilmu-Ilmu AlQur'an Dan Hadis, 19(1), 43-63.

Fiteriani, I. (2015). Membudayakan Iklim Semangat Belajar Pada Siswa Sekolah Dasar. TERAMPIL: Jurnal Pendidikan Dan Pembelajaran Dasar, 2(1), 115125.

Fitriana, D. N. I. (2013). Pengaruh Iklim Sekolah dan Kepuasan Kerja Terhadap Kinerja Guru SD di Kecamatan Muntilan Kabupaten Magelang. Hanata Widya, 2(4).

Freiberg, H. J. (1999). School climate: Measuring, improving, and sustaining healthy learning environments. Psychology Press.

Goetsch, D. L., \& Davis, S. B. (2014). Quality management for organizational excellence. pearson Upper Saddle River, NJ.

Gunbayi, I. (2007). School Climate and Teachers' Perceptions on Climate Factors: Research into Nine Urban High Schools. Turkish Online Journal of Educational Technology-TOJET, 6(3), 70-78.

Halawah, I. (2005). The relationship between effective communication of high school principal and school climate. Education, 126(2).

Hapsari, O. (2014). Pengaruh Iklim Sekolah Terhadap Kedisiplinan Belajar Siswa Kelas VII Di SMP Teuku Umar Semarang [PhD Thesis]. Universitas Negeri Semarang.

Haynes, A. B., Weiser, T. G., Berry, W. R., Lipsitz, S. R., Breizat, A.-H. S., Dellinger, E. P., Herbosa, T., Joseph, S., Kibatala, P. L., \& Lapitan, M. C. M. (2009). A surgical safety checklist to reduce morbidity and mortality in a global population. New England Journal of Medicine, 360(5), 491-499.

Insyiroh, L. (2017). Studi Tentang Penanganan Siswa yang Terlambat Tiba di Sekolah oleh Guru BK SMA Negeri 1 Gresik. Jurnal BK Unesa, $7(1)$.

Irsyad, M. (2019). Pendidikan Seks untuk Anak Usia Dini: Tindakan Pendampingan dan Pencegahan. Elementary: Jurnal Ilmiah Pendidikan Dasar, 5(1), 73-86.

Komariah, A. (2014). Pengaruh kepemimpinan transformasional, iklim sekolah, kinerja mengajar guru terhadap produktivitas sekolah. MIMBAR: Jurnal Sosial Dan Pembangunan, 30(1), 118-125.

Magfirah, U., \& Rachmawati, M. A. (2010). Hubungan antara iklim sekolah dengan kecenderungan perilaku bullying. Jurnal Universitas Islam Indonesia.

Mayring, P. (2004). Qualitative content analysis. A Companion to Qualitative Research, 1(2), 159-176.

Moberly, D. A., Waddle, J. L., \& Duff, R. E. (2005). The use of rewards and punishment in early childhood 
classrooms. Journal of Early Childhood Teacher Education, 25(4), 359-366.

Mutmainah, M. (2017). Perilaku Kepemimpinan, Iklim Sekolah Dan Sekolah Efektif. Jurnal Administrasi Pendidikan UPI, 24(1), 163-172.

Patton, M. Q. (1990). Qualitative evaluation and research methods. SAGE Publications, inc.

Pohan, R., Fitrianti, L., \& Siregar, R. H. (2017). Program Mushafahah (Bersalaman) sebagai Upaya Character Building pada Siswa Sekolah Dasar Islam Swasta Pekanbaru. Belajea; Jurnal Pendidikan Islam, 2(1), 01-20.

Pretorius, F., \& De Villiers, E. (2009). Educators\$backslash\$'perceptions of school climate and health in selected primary schools. South African Journal of Education, 29(1), 33-52.

Rahayu, S. (2020). Hubungan Iklim Organisasi dengan Semangat Kerja Guru di SMK Negeri I Kecamatan Ampek Angkek Kabupaten Agam. Jurnal Bahana Manajemen Pendidikan, 4(1).

Rahmawati, F. (2013). Pengaruh Pendekatan Pendidikan Realistik Matematika dalam Meningkatkan Kemampuan Komunikasi Matematis Siswa Sekolah Dasar. Prosiding SEMIRATA 2013, l(1).

Rahmawati, I. (2011). Pengaruh Iklim Sekolah Dan Motivasi Kerja Terhadap Kinerja Mengajar Guru Smk Di Kota Bandung. Jurnal Administrasi Pendidikan, 21(2), 115-122.

Razak, A. Z. A. (2006). Ciri iklim sekolah berkesan: Implikasinya terhadap motivasi pembelajaran. Jurnal Pendidikan Malaysia (Malaysian Journal of Education), 31.

Setiawan, A. (2016). Kontribusi Kepemimpinan Transformasional
Kepala Sekolah dan Iklim Sekolah Terhadap Efektivitas Sekolah. Jurnal Administrasi Pendidikan, 23(1).

Sgier, L. (2012). Qualitative data analysis. $A n$ Initiat. Gebert Ruf Stift, 19, 19-21.

Silverman, D. (2020). Qualitative research. Sage Publications Limited.

Solikah, S. N. (2018). Upaya Peningkatan Kesadaran Prilaku Hidup Bersih Dan Sehat Pada Anak Usia Sekolah (SD). GEMASSIKA: Jurnal Pengabdian Kepada Masyarakat, 2(1), 56-64.

Stake, R. E. (2005). Qualitative case studies.

Sumarsono, R. B. (2012). Iklim Sekolah, Komitmen Organisasi, Kepuasan Kerja, dan Kinerja Guru. Manajemen Pendidikan, 23(6), 532-539.

Syafaruddin, S. (2015). Manajemen lembaga pendidikan Islam.

Syafaruddin, S. (2019). Kepemimpinan Pendidikan: Akuntabilitas Pimpinan Pendidikan Pada Era Otonomi Daerah.

Tubbs, J. E., \& Garner, M. (2008). The impact of school climate on school outcomes. Journal of College Teaching and Learning, 5(9), 17.

Wan Roslina, W. I. (2011). Korelasi Amalan Kepemimpinan Pengajaran Pemimpin Pertengahan Dengan Iklim Sekolah, Sikap Guru dan Komitmen Organisasi di Sekolah Menengah Kebangsaan [PhD Thesis]. Universiti Utara Malaysia.

Weijers, I. (2000). Punishment and upbringing: Considerations for an educative justification of punishment. Journal of Moral Education, 29(1), 61-73.

Welsh, W. N. (2000). The effects of school climate on school disorder. The Annals of the American Academy of Political and Social Science, 567(1), 88-107. 
Yuliejantiningsih, Y. (2012). Hubungan Iklim Sekolah, Beban Tugas, Motivasi Berprestasi, dan Kepuasan Kerja Guru dengan Kinerja Guru SD. JMP.(1), 3, 239-256.

Yuniarn, D. (n.d.). Penggunaan Hukuman Yang Edukatif Dalam Membentuk Perilaku Disiplin Anak Di Ra
Babussalam. Jurnal Pendidikan Dan Pembelajaran Khatulistiwa, 5(06).

Zullig, K. J., Huebner, E. S., \& Patton, J. M. (2011). Relationships among school climate domains and school satisfaction. Psychology in the Schools, 48(2), 133-145. 